$1 \cdots$

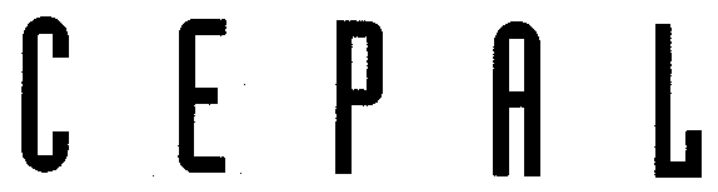

REV IE W

NUMBER 49

APAIL 1993

SANTIAGO, CHILE

ANIBAL PINTO

Director

EUGENIO LAHERA

Technical Secretary

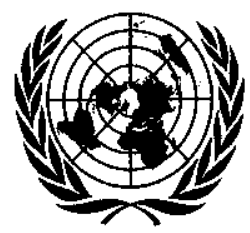

UNITED NATIONS 
Women in the region: major changes Miriam Krawczyk

The Pacific Basin and Latin America Dae Won Choi

The trade union system: its background and future prospects Fernando Calderón $G$.

Shaping competitiveness in the Chilean wood-processing industry

Dirk Messner 


\section{The trade union system: its background and future prospects}

\section{Fernando Calderón G.}

Regional Expert on Social Development in the ECLAC Social Development Division. This article is based on a paper presented at the Symposium on the Response of Trade Unions, the Political System and the State to the Crisis and Structural Change: European and Latin American Experiences (São Paulo, August 1992).
Since the early 1980 s the labour movement has had to deal with a series of radical changes in Latin American society and in its own identity. These transformations have been linked to the political changes associated with the termination of dictatorships, the transition to democracy or alternatively the weakening of democratic systems, and to economic changes brought about by the crisis, the external debt, the social consequences of adjustment policies, and the de-industrialization and retrofitting processes. The trade unions are having to cope with the close of one stage in history -a stage marked by a model of dependent industrialization and a neo-corporate, proprietary State- and the beginning of another -a stage of industrial renewal based on technological innovation and a democratic State - whose outcome is highly uncertain. Criteria and forms of sociopolitical legitimacy are being redefined at such a dizzying pace that trade-union structures and policies themselves are being transformed, as also (at a more theoretical level) is the relationship between politics and economics. This article, based on case studies of Argentina, Bolivia, Brazil, Chile, Paraguay and Uruguay, explores these issues with particular attention to the as yet erratic efforts that are beginning to be made to devise innovative strategies for the trade unions' participation in the restructuring and modernization processes. This innovation is starting to engender what might be thought of as a cultural pattern of flexibility. 


\section{I}

\section{The sociocultural setting}

\section{and the economic outlook}

As we approach the threshold of a new century, we must ask ourselves: What is happening to the workers and entrepreneurs who, through conflict, built the most powerful cultural ethos of the modern world? How can we go about devising, from the vantage point of our society, a new, integrative, politically democratic model of economic development?

For Latin Americans, industrialization has been directly linked to the building of their nations and States and to the creation of political parties and institutional systems, the emergence of modern values and, most of all, the deep desire for an integrative form of economic development. Industrialization has also brought, especially for the workers, hard-won victories on the battleground of political and social citizenship. The truth is that the Latin America of the twentieth century would be unimaginable without the cultural contributions made by workers in all spheres of economic and political affairs.

In seeking to create this modern-day ethos, workers were not only striving to define their central role in history. Their actions were primarily directed towards different horizons, such as the national/popular or communist movements and their potential in the continent; but they also made us think about death and the absurdity of the labours of Sisyphus. What peasant farmer, what student, doctor or artist did not see himself reflected in the workforce and in the labour movement? What employer did not think about the role that unionized workers might play in his factories?

Is all this disappearing? Or is it only that a certain way of thinking about the construction of today's modern societies is coming to an end? What other proposals are surfacing? Is structural adjustment the first step in an historic action? What role can workers play in this process besides simply putting up resistance? Is it a viable proposition from a political standpoint to seek to change production patterns with social equity? Do modemization and democratization mix?

For the time being, the most salient fact is that the dependent form of industrialization we have pursued during the twentieth century has been a failure. It is also quite clear how deeply workers and modern Latin American culture have been affected by technological retrofitting and the resulting robotization and automation of industry. After retrofitting, industries seem to employ no more than a handful of workers. Does this mean that action by workers on a global or international scale is no longer possible? Will medium-sized and small industries become extinct in the not-too-distant future, with all the effects this would have on vast numbers of workers? What social and political options will the market, the State and the political apparatus offer to these workers?

Perhaps the pivotal element in these issues, which are beginning to be a cause of concern for the peoples of the region, is the emergence of a "programmed society", i.e., a society increasingly based on computerized communications and programming in which the market and the cultural industry (which is more and more a product of transnational corporations) spoon-feed us advertising about products we do not make but might fancy consuming. Can workers do something about this, or are we witnessing the birth of a new, cybernetic society that heralds the advent of an unprecedented potential for human action of an increasingly systemic nature, one that does not allow for sociocultural and political action or conflict?

Most likely, it will be neither one extreme nor the other. It is true that things are changing at a dizzying pace, but it is also true that the basis of those changes is the societal actors' own cultural experiences.

The social contract which led to the emergence of the Welfare State in developed countries, and which included entrepreneurs, the State and workers, began to disintegrate and then to reshape itself in the $1970 \mathrm{~s}$ and 1980s. This gave rise to a new socio-historical matrix whose core elements are the retrofitting, communications and business management processes and whose main driving forces are the transnational corporations, the scientific/technological and administrative intelligentsia, and the modernized State. When thinking about this process, we should remember, as Manuel Castells has noted on repeated occasions, that the world economy is beginning to function 
more and more as a single time-unit in which the processes of industrial retrofitting, communications and management are the forces that organize the development of national economies (Castells, 1988). This dynamic is so powerful that the existence of autonomous national economies is becoming increasingly untenable. The growth of the market and productivity are directly related to the rationale of management and, especially, to the use of the time between technological research and new consumption patterns.

The technological revolution, especially in the fields of information sciences, electronics and telematics, is aligning the associated changes into a cross-configuration. Put very briefly, it would seem that society is beginning to make the transition from employment-based social relations to relations based on modes of information in which the connection between knowledge and its symbolic interactions with the political system is starting to play a fundamental role.

The changes occurring in the productivity of capital, primarily as a result of investment in science and technology and the concentration of the highest rates of productivity in the electronics industry, along with new sorts of working conditions based on workers' capacity for action and use of information, are important examples of this new dynamic. 1

In Latin America, however, these potential innovations are heavily dependent upon the characteristics and direction of the economic restructuring processes and, in particular, the characteristics of the adjustment.

Although adjustment policies have certain general traits in common in almost all parts of the region, especially during the stabilization phase, their actual implementation varies not only because the conditions in each country differ, but also because of the nature of the times and political processes they have lived through. Thus, Chile -where the early stages of the adjustment were carried forward by a military regime virtually without the presence of any strong social actors- is clearly a different case from Brazil, where the adjustment process is only just beginning and trade unionism is a socially and politically strong movement, all this within the framework of a weak democratic system.

Hence, we would be ill-advised simply to settle for an automatic, all-embracing ideological description of neoliberal policies. It is important to specify how and how much these policies are affecting productivity and the market and whether or not they are

\footnotetext{
${ }^{1}$ For a statistical analysis of productivity by industrial sector and of the corresponding technological impact, see CIEPl, 1984.
}

linked to the bureaucratic practices and featherbedding associated with times gone by. It is therefore necessary to gain an understanding of the different time lags that can arise in economic adjustment processes and their implications for the retrofitting of the production apparatus, social equity and the stability of democracy -i.e., their effects in terms of the pace, stages, course and intensity of adjustment policiesand of the roles played by the various political agents. The range of possibilities will surely differ from country to country, as will their consequences for the trade unions.

Indeed, some trends are already in evidence which demonstrate the need for a more detailed analysis. One example is the case of recurrent adjustments that produce stability but no economic growth or social integration. Another example is that of adjustments which bring only fleeting economic reactivation or which are confined to the export cycle, so that they eventually saturate the available external markets (which, moreover, remain segmented and protected). In essence, the minimum goal for virtually all the various types of adjustment policies is the governance of the economy and the maintenance of a balanced democracy, while their more ambitious strategies envisage progressive governance and successful retrofitting. The achievement of these goals will depend as much on the matrix of social and political forces in each country as it will on the limited economic prospects of the region as a whole.

According to a number of recent prospective studies, Latin America's share in the world economy will continue to shrink during the $1990 \mathrm{~s},{ }^{2}$ and the region will be heavily influenced by the economic shifts associated with changes in the developed countries.

\footnotetext{
${ }^{2}$ See CIEPI, 1984, and Bouzas, 1988. By way of example, the projections of per capita gross domestic product (GDP) prepared by CIEPI for each region indicate that the economic gap between rich and poor countries will widen further: Latin America's per capita GDP is expected to climb from around US\$2,500 to US\$ 3,000 between 1990 and the year 2000, whereas that of the United States will rise from US $\$ 14,000$ to US $\$ 17,000$, Japan's will go from US $\$ 12,000$ to US\$15,000, that of the EEC will move up from US\$9,000 to US\$12,000 and that of the newly industrializing economies (NIEs) will jump from US $\$ 6,000$ to US\$11,000; in sub-Saharan Africa, on the other hand, per capita GDP is expected to remain at US $\$ 500$ (see CIEPI, 1992). From the standpoint of social differentiation, a recent ECLAC study covering the period 1960-1980 on 32 countries that are either located in the Latin American and Caribbean region or belong to the Organization for Economic Cooperation and Development (OECD) found that the social gap between the Latin American and $O E C D$ countries was growing wider, that developed countries were becoming more homogeneous and that the inequalities among the countries of the region were becoming greater (ECLAC, 1992a).
} 
Within this context, these studies outline two foreseeable scenarios. On the one hand, if the central economies do not undergo any major changes, then the region's economies may maintain their limited rates of economic growth and expand their export markets to some extent without, however, managing to reverse the regressive trend of income distribution. On the other hand, if the developed economies slip into recessions, then the Latin American economies will experience a greater deterioration in their own situation, and external factors may even derail their adjustment processes.
The outcome will surely depend as much on the specific traits of each country's economy -particularly the stage reached by its retrofitting process, its degree of political stability, the extent of its export diversification, and its supply of petroleum and other natural resources- as it will on the quality of the sociopolitical matrix and the institutional power of its social actors (Calderón and dos Santos, 1992, chap. 6).

Given its experiences and its potential for influencing the path of history, the working class can play a fundamental role in all of this, provided that it first reforms itself. An attempt is made to analyse this question in greater detail in the following section.

\section{II}

\section{The social and historical background}

As from the early 1980 s, the labour movement had to cope with a series of radical changes in Latin American society and in its own identity. These changes were associated with such political changes as the end of dictatorships, transitions to democracy or, alternatively, the weakening of democratic systems, and also economic changes linked to the crisis and the external debt, to the social implications of adjustment policies (e.g., decreases in wages, in employment and in workers' quality of life) and to the de-industrialization and retrofitting processes, with all the social costs they entail.

In the 1990s, trade unions are having to deal with the close of one stage in history -a stage marked by a model of dependent industrialization and a neocorporate, proprietary State- and the beginning of another -a stage of industrial renewal based on technological innovation and a democratic Statewhose outcome is still uncertain.

These are times during which criteria and forms of sociopolitical legitimacy are being redefined, and these changes are taking place so rapidly and so tumultuously that the trade unions' structures and policies themselves are being transformed, as also, at a more theoretical level, is the relationship between politics and economics.

Furthermore, as we noted earlier, this dynamism is part of a series of highly internationalized changes. To a great extent, these problems and experiences are shared by the societies and trade unions of developed and developing countries. Nevertheless, the socioeconomic bases are different, since crises and restructuring processes in developed countries took place in the presence of a stronger Welfare State and more socially integrative markets, whereas in Latin America the market has not, for the most part, been a source of social integration or equity. Once the nationalist/popularist regimes faded away, the State devoted itself to featherbedding, corporate relations and narrowly-defined private interests rather than concentrating on the promotion of social integration and development. In contrast to the situation in areas such as South-East Asia, economic growth in the region -particularly in countries under authoritarian rule- has had nothing to do with social integration (ECLAC, 1990).

In the early 1980s, economic activity dropped off sharply and the dependent industrialization model began to falter. Hyperinflation and attempts to use adjustment policies containing a large fiscal component to achieve economic stability were typical features of the social and political scene of the period. One of the actors that was the most strongly affected by these policies was the State, as was reflected, for example, in cuts in public spending, the curbing of demand, the elimination of subsidies, the achievement of a fiscal balance, the lifting of price controls and deregulation.

Within this environment, the trade unions oscillated between taking action to promote democracy as a basic right and taking defensive action against the effects of the economic crisis and adjustment policies. 
The union movement took three different paths during those years. The first, which predominated in COlombia and Venezuela, encouraged the trade unions, at least in the early days of the crisis, to remain subordinate to the State and the major political parties rather than seek some degree of institutional autonomy as a class (later on, these partnerships or pacts broke up or splintered). The second, which was followed by most trade unions in the Southern Cone, concentrated on the formulation of demands for the recovery or establishment of the political and social rights of citizenship. The third was directed towards the consolidation of a form of institutional autonomy that was closely associated with criticism of the political parties. In this last connection, there are two cases which were very similar in terms of social autonomy but whose dynamics were quite the opposite of one another: on the one hand, there was the crisis experienced by the Bolivian Workers' Confederation (COB) and its loss of power, while on the other, there was the upsurge and strengthening of the Brazilian union movement. The former was associated with the political crisis in the Left and the collapse of the tin market, while the latter was related to the decline of authoritarianism and the growth of sophisticated industrial activities.

These new situations and experiences are all reshaping the role of the trade unions in contemporary society, both in terms of their identities and their forms of organization and action and as regards the relationship between the union movement and other sociopolitical and cultural actors. This has forced the unions to see themselves and others in a different light and, ultimately, to redefine workers' identity and place in modern society on the basis of their own cultural and historical experiences. Crucial aspects in all of this are the linkages between workers and new technologies and those linkages' sociopolitical and cultural implications.

\section{III}

\section{Technology and images}

According to a study coordinated by L. Coutinho and W. Suzigan, the main directions of technological change are related to the following factors: the growing importance of the electronics industry within the industrial matrix; flexible production capabilities and the merging of mechanical engineering with digital electronics; the revolution taking place in the realm of work processes, which is giving the labour force a bigger role in the management of the production process; the transformation of business structures and strategies; the new foundations for competitiveness; the intensification of the internationalization process and the economy's oligopolization by sector and product category; the globalized management networks of many businesses; the interrelated ownership of equity and financial capital together with the close interconnection between financial and exchange markets and investment portfolios; and the new cooperative alliances formed among major oligopolistic groups on the basis of new production technologies (Coutinho and Suzigan, 1990, as cited in Da Silveira, 1992).

A recent ECLAC study demonstrates the complexity and heterogeneity of workers' images and perceptions in relation to technological innovation. A brief summary of a portion of that study's findings will shed some light on the trends observed (ECLAC, 1992b).

According to the results of interviews with trade union members in different industries in Chile, $\mathrm{Ar}$ gentina and Brazil, technological change is regarded as something that is determined by transnational corporations and as a form of external power and domination which is not exactly the outcome of internal evolution but which is nonc the less an inevitable process. The interviewees therefore saw a need for workers to participate in the modernization process. The "appropriation" of new technology is essential in order to escape subordination to it. Within this context, technology appears to be closely linked to new power relationships and to the political processes associated with them: "in order to become knowledgeable about technology, one must have access to information, and having control over such knowledge is a source of power; this is why the trade unions demand the democratization of the power afforded by technology and information" (ECLAC, 1992b, p. 150). 
The interviewees felt that the most negative aspect was the unemployment caused by the introduction of new machinery and the anxiety provoked by the resulting job instability. They also, however, realize that companies have to modernize if they are to remain in business and that, in this sense, new technologies help to maintain existing sources of jobs.

New technologies also call for more highly skilled and trained workers, however, and this type of training is generally not provided either by employers or the formal education system. The study notes that all the interviewees complained about the companies' performance in regard to training.

On the other hand, a positive attitude is taken to the new technologies as such. Some think that these technologies will "humanize" existing jobs, since less physical effort but more intellectual effort will be required, which will give workers greater autonomy. Fewer supervisors and technicians will be needed, because the work will all have been designed by computer and will therefore require less supervision (others, however, believe that, even with fewer supervisors, it will become easier to bring pressure to bear upon them). Workers will not be displaced by new machines; they will be interrelated with them, since the worker will then have the "power" to give the machine its instructions either correctly or incorrectly. The use of new technologies may therefore require more responsible behaviour and closer attention from workers, and the value of each machine will also be transferred to the worker who runs it.

Other interviewees, however, felt that the use of these technologies leads to a loss of creativity and turns workers into virtual robots, as well as engendering occupational stagnation and reducing the career prospects of workers, since the highest-ranking posts will go to highly skilled professionals. ("Promotion can no longer be won on the basis of hands-on experience", said one man interviewed in a Chilean mining company.) There may also be a loss of "worker solidarity" in the workplace, although this has more to do with labour's new organizational pattern than with the use of technology per se (since workers perform their jobs alone and in isolation).

Some interviewees felt that technological innovation would help to raise their occupational status, but others thought that it would do just the opposite by, in effect, expropriating workers' skills and incorporating them into the new machinery. Still others said that workers' job status might rise or fall depending on the particular type of industry in question; for example, a lathe operator might see his status enhanced but a process worker in the petrochemicals industry might lose status.

All the interviewees criticized the practice of confining the use of technology to production activities alone. Technology should also be placed at the service of society as a whole to improve education, health care, living conditions and working conditions. The workers interviewed felt that firms should be aware of their responsibility to society, and they criticized the speculative attitude of management (Argentina), the harshness of the policies maintained by employers (Chile) who feel they "own" the modernization process (especially in export-oriented agricultural activities), their insensitivity to social conditions, and their habit of viewing labour relations only as a function of production, with no consideration of working conditions. These workers want to share in the productivity made possible by the use of new technologies; they want job stability and the possibility of career development, and they want the workplace to be humanized and working conditions to improve. Concern about the need to professionalize management and technical functions was also expressed.

When all these ideas and views are considered in the aggregate, they not only attest to workers' sensitivity, concern and interest in technological innovation; they also bespeak a positive attitude about the need for knowledge as a fundamental factor in terms of their own action and participation in the economic restructuring process. If this view takes hold and becomes widespread, workers will play an active role in the new social order that is emerging. 


\section{IV}

\section{Current trends in the trade}

\section{union movement}

\section{as a turning point in history}

During the 1980s, trade unions took a defensive, pragmatic approach in dealing with the social repercussions of the crisis and economic stabilization policies on a case-by-case basis; during the $1990 \mathrm{~s}$, in addition to coping with the consequences of the adjustment and restructuring processes, they will also have to develop their own capacity for cultural modernization and innovation.

The issues of representation, scientific and technological knowledge, and the recognition and projection of ethical and aesthetic values relating to autonomy, diversity and tolerance will play a fundamental role in building a new institutional order and in revitalizing national development strategies.

Against this backdrop, considerations regarding the reform or modernization of the State and, hence, the reformulation of the relationships between the State, society and the economy will surely be essential elements in future union action as well.

Some aspects of the present situation in selected countries in relation to these issues will be summarized below.

Although Argentina's chronic economic instability and its associated industrial stagnation now seem to be a thing of the past, the fact remains that during the 1980 s the country's de-industrialization and the de-proletarization of its society deepened and were accompanied by a greater degree of economic concentration and a highly regressive pattern of income distribution (Palomino, 1991), as well as a progressive reduction in the importance of the State's role in the economy.

Thompson (1992) contends that, under these circumstances, the phenomena having the greatest impact on the behaviour of the trade unions were the contraction of the labour market, the decrease in workers' wages, the shrinkage of the public sector and the cuts made in social spending. When trade union members split into two different confederations, the prospects for a new social contract became even more remote, since this reduced the movement's power to take action, both at the national level and in respect of the union rank and file, as well as gradually eroding its ability to veto the Government's policies. This situation revived the issue of the trade unions' ability to represent their members and their functionality within the framework of the adjustment and economic restructuring processes. More specifically, trade union practices in Argentina at the present time reflect the preponderant role being played in the public arena by unions in the services sector, the more prominent position of public-sector trade unions, and the greater heterogeneity of union organizations themselves.

Within this setting, the relations of the two union confederations and the principal sectoral organizations with the Government have ranged from a defensive form of opposition marked by a relative absence of social mobilization and a very scant degree of influence over the definition of national economic and social policy, to wholehearted support for the Government and its economic policies. It would seem that, ultimately, ideologized isolationism and subordinate pragmatism both serve to hasten the decline of the workers' presence in the political decision-making system. What really seems to be at stake here is the way in which the trade unions will relate to the processes of reform of the State and retrofitting of the economy.

Nevertheless, although dispersion, resignation and pragmatism may be the dominant traits of Argentine trade unions today, the redefinition of a more autonomous union movement -one which would be more of a social than a political force- is also an important issue for discussion by union members.

In Uruguay, the union movement has had a number of difficulties, but it has none the less managed to remain united and to play an important role in the political and economic affairs of the country. The track record of CONAPRO (the Uruguayan trade union confederation) and its experience in negotiating with the Government and with employers' associations have enabled it to acquil itself quite well in the 
ongoing debate and dialogue with the Government (the social dialogue) regarding wages, employment and prices, reform of the State, integration and the retrofitting of the production apparatus.

Above and beyond the vagaries of present circumstances, the key elements in the Uruguayan situation --both for the State and for the social actors-are the tensions that exist between a strategy of cooperation and one of confrontation and between a closed, defensive position and sociocultural innovation in social practices themselves. Here, the labour movement may have a number of comparative advantages that give it an edge over other social actors. In that connection, Jorge Notaro has said that the union movement tends to place greater value on productivity and investment as a necessary foundation for an improvement in living conditions in the country (Notaro, 1992). Nevertheless, policies on reform of the State, especially those referring to the rationalization of the institutional structure, privatization and new employment regulations, are important elements for the country's democratic and economic future, since Uruguay is currently witnessing the configuration not only of a new economic/production profile, but also of the union movement's position and significance in the nation's democratic reconstruction.

The Trade Union Congress (CUT) in Chile is one of the leading actors in the country's transition to democracy and in its consensus-building process, in which tension between the Government, management and the labour unions is now often eased through dialogue and the conclusion of agreements among these parties on an equal footing. The cUT has, however, been temporarily deferring a series of demands regarding fuller recognition of its labour-related rights and its right to participate in political affairs. The rebirth of a strong party system in Chile has somehow been a factor in inducing the trade unions to play a new role as an autonomous social force which has its own political influence but is, none the less, subordinate to the ruling political parties. It must surely be the case, however, as Guillermo Pérez has said, that both Chilean society and the Chilean trade unions have a vision of the future that includes the challenge of defining a socially inclusive form of modernization that will ensure equitable development (Pérez, 1992).

María E. Feres' studies on trade unions have led her to conclude that the key elements needed for the development of labour relations are more efficient systems of union representation and representativity, a predominantly cooperative form of action among the social actors, and the modernization of the production apparatus, together with the adaptation of workers' rights to fit new situations. Thus, issues such as the need to make the labour market more flexible, the provision of unemployment insurance, the continuity of social benefits and ongoing training for workers are some of the basic ingredients in a socially inclusive form of economic modernization (Feres, 1992).

As a result of the political transition and their long struggle to establish a national labour movement in Paraguay, the trade unions of that country are still in the process of laying their foundations and of winning recognition as a sociopolitical actor in the nation's society and its decision-making system. The reform of the labour code and the possibility of a new constitution are surely indications of this. Céspedes (1992) argues that the unions are making a transition from a corporative and party-based movement linked to the State and the Colorado Party towards a movement which is pluralistic in terms of both the trade unions themselves and the market. Within this new setting, he sees the government-endorsed Paraguayan Workers' Confederation (CPT), the United Workers' Confederation (CUT) and the National Workers' Confederation (CNT) all coexisting in competition with one another, each with their own specific types of political-party links and with different avenues for exerting an influence on society; the greatest challenge posed by such competition among different trade unions would lie in the changeover from being an opposition force to a source of constructive proposals; as in the cases of the labour movements in Argentina, Brazil and Uruguay, this transition may be further complicated by subregional economic integration processes, such as, for example, MERcosur.

During the period from 1989 to 1992, which was a time of continuing economic and political stability in Bolivia, the nation's labour movement found itself in the midst of a series of conflicts as it strove to reclaim its functional role within society. These conflicts revolved around the nature of socially-oriented employment and services-infrastructure policies, wages and working conditions for teachers, disputes between State mining companies and workers over comparative risk policies, disputes relating to the production and sale of coca, budget policy and, in particular, policies on reform of the State, especially in regard to decentralization and privatization. With regard to the latter, the trade unions managed to persuade the Government to enter into an agreement 
whereby the privatization of State companies must be approved on a case-by-case basis.

According to Jorge Lazarte, the union movement in Bolivia seems to be entering a phase of redefinition, since it is apparently developing some of the capacity for negotiation that it has traditionally lacked. During the period in question, he contends, the Bolivian trade unions have become defensive, instrumentally-oriented, and primarily concerned with expressing their grievances and demands (Lazarte, 1992). Their disputes and struggles have become fragmented. The union leadership, however, especially at their congresses, continue to focus on strategy formulation (Rivera, 1992). Since these developments have been accompanied by a steep drop in the total wage mass as a result of the recession, one of the issues that the labour movement will probably have to address, besides its modernization, will have to do with its representation and representativity in national affairs.

The growth of the union movement in Brazil has been closely linked to the processes of industrialization and social differentiation taking place in that country over the past 30 years, especially since the 1970 s and the famous strikes of the metal workers of São Bernardo. The trade unions have gone back and forth between concentrating on fighting for better wages and working conditions, asserting the identity of the labour movement, and joining in the sociopolitical dynamic of Brazil's transition to democracy
(Abramo, 1986; Da Silva, 1981). The development of a new sense of dignity among workers -which is not unrelated to the exclusion and degradation of workers by employers and the authoritarian State- has also engendered a renewed esteem for industrial modernization although, despite its strong political impact on the nation, this process has thus far not provided the means to ensure political stability or to restructure the economy.

In view of the crisis situation in Brazil's economy and industries, however, the use of strikes as the main form of union action has not provided the trade unions with a way to move beyond reactive and grievance-based modes of activity to a point where they might define more strategic positions regarding the retrofitting of the economy and the construction of a more socially integrative economy (Barbosa de Oliveira, 1992).

This is surely linked to their experiences during the application of the developmentalist model cham. pioned by the military government, as well as to the marked heterogeneity and segmentation of Brazilian society itself, which limits the potential for cooperative, consensus-based strategies. Da Silveira (1992) raises this issue once again and envisions the possibility of a new national production and social integration pact whose core component would be composed of strategies for reintegration into the new technological paradigm.

\section{V}

\section{Political reform and strategies for innovation}

For some time now there has been a sociological thesis which encompasses the above considerations. It holds that development and the consolidation of democracy in the region can only come about if the social agents' capacity for action is strengthened (Calderon, 1988).

Such a daring sociological proposition entails three fundamental challenges which are linked to the possibility of certain changes taking place in Latin American society.

The first challenge is to recreate, on the basis of Latin America's own national/popular (and, in this case, classist) historical background, a forum for the political representation of social concerns: in other words, an institutional arena in which the actors -whether directly or via political parties, in conflict or not- can make their demands heard and can express their interests as a means of arriving at the consensus necessary for furthering development. The issues of democracy and local development could certainly play a crucial role, both as a form of democratic affirmation and as a technological catalyst.

The second challenge is to devise a policy for the social -and above all the political- integration of the poorest sectors of our societies. Only if they are politically autonomous can these sectors fight for their 
social integration on their own; this would, in effect, amount to recognition of the political citizenship of men who, when all is said and done, already fought for it a century ago with Bolivar.

The third challenge is to strengthen the State by modernizing it and adapting it to the new features of the transitional society in which we live, yet at the same time subordinating it to the institutional logic of democracy. The State will surely continue to be a leading actor in the modern world for a long time to come, and the types of reforms -which are, in any case, indispensable - that are introduced will be of strategic importance for our societies. The problem lies in how they will affect decision-making, since what is at stake here is the alteration of the State's system of decision-making and the extent of the influence which the democratic system of government will have over it.

Essentially, strategies for innovation relate to the trade unions' search for an active role in the restructuring and modernization processes of Latin American society. Unless they forge a role for themselves, decisions affecting the unions and their societies will be taken by others. ${ }^{3}$

As Lanzaro has argued in such a thoughtprovoking manner, the process of innovation needs to be set within a culture which fosters a flexible response to the new socio-historical processes we are now living through (Lanzaro, 1991).

One of the most compelling reasons, from a societal standpoint, why we must think about the need to ensure that workers will play a more active role in the current restructuring process is its exclusive, fragmented rationale, which is a result, inter alia, of the weakened position of the trade unions and the State and the stronger position of business interests.

The trade unions' structures and functions are increasing in complexity at a dizzying pace in terms of their relationships with both employers and the State and with the rest of society.

\footnotetext{
${ }^{3}$ For an illustration of this situation, see the monograph (ACINDAR) on the subject by Palomino and Novick (1992), which analyses the tensions existing within the union movement in connection with the restructuring process.
}

In coming years, the union movement will have to continue to remember and understand the fact that political and institutional stability are necessary conditions for the retrofitting of industry and the achievement of social equity as well as for the modification of the unions' own representative structures. It will also have to continue dealing with the reform of the State, whose policies on privatization, decentralization and social issues may pave the way for a convergence of interests with other social and political actors, whether public or private, external or internal. This convergence would permit a joint redefinition of the necessary conditions for the re-establishment of the unions' position within the new international economic and cultural structure and the construction of a democracy which maintains some sort of balance of power in its decision-making processes and in terms of participation in modern public life.

The cultural pattern of flexibility mentioned earlier would, in this sense, serve as a means for innovation, adaptation and facilitation of an ongoing flow of information about processes of change whereby the political attitudes of the trade unions would include a revitalizing approach to the management of complexity and uncertainty without, however, setting aside the values of solidarity, autonomy and liberty which have been consubstantial with the past experience of workers.

Taking part in the restructuring process, democratizing the flow of information and knowledge, gaining access to communications systems and expanding their system of representation in an effective manner are probably the central components of many Latin American trade unions' new strategies of innovation. In order to pursue these strategies in practical terms, the unions' legitimate specific and individual demands must be linked up with existing processes of nation-building. The aggregation of demands, the rationalization of their conduct and the politicalization of their interests can help workers to play a more effective and constructive role in modern society. It must be remembered, however, that the desired political constructs entail a system of ongoing interaction by the social actors. The strength of a given party or class will depend on how well they can champion their interests within the institutional structure and how effective they are in reaching agreements with their opponents. 


\section{VI}

\section{Political and cultural forces}

Rather than being more innovative, the democracies of today are becoming increasingly querulous and unstable. With each passing day it is also becoming clearer that economic adjustment programmes -which are a strong force of social differentiation, especially if they do not include significant compensatory mechanisms- are, in the long run, sources of political instability and social chaos. Thus, it is worth asking ourselves whether reintegration into a programmed society is possible without the reactivation of the social and cultural actors. That reactivation does not, however, appear to be taking place.

From what source can these faltering societies draw strength? The political and cultural spheres are the only possible answers. Politics, because it is the only arena in which the disaggregative processes now under way in the countries might be brought together into a unified whole; only political action on a nationwide scale can hope to elicit an integrative response from the societal actors, and only politics can raise the issue of the State and development under different conditions. Culture, because in the final analysis, only history and cultural experiences can shape the tolerance and the work ethic which are these societies' source of strength. Is this enough? Or must there also be some other way of relating to technology and, in particular, to the informational and cultural dynamism of programmed societies? I believe the latter is the case.

However, unless our societies and actors strengthen themselves, we will only manage to build scattered strongholds of modernization on a vast wasteland of poverty where, eventually, perhaps not even these strongholds will remain. Or to put it another way: if we choose the path of giving greater power to our societies, we are also choosing the path of rational political action over the long term.

Perhaps, in these times of change, workers, too, can use their traditional forms of action -which have been more politically than socially oriented-and their political culture -which has been of a more corporative and heroic, rather than pluralistic, cast- to aid in the effort to fashion a network of social and political actors devoted to building a bridge between modernization and democracy. After all, they carry on their shoulders a whole body of modern rational experience. Can they do it? And if they do, will other political and social actors join them? When all is said and done, the democratic modernization of our societies must be a shared political creation.

A major problem is appearing on the political horizon, however. That problem is the dynamic of historical time, in that, while collective action remains on the defensive and continues to slowly accommodate itself to the adjustment, the adjustment is proceeding full steam ahead -with no prise de conscience whatsoever- to alter the State, the economy and the political activity of our societies. While it is true that adjustment policies are introducing these changes, it is also true that their implementation is eroding society's ability to form a consensus, weakening the efforts being made to build democracy, and actually reducing the chances of retrofitting the economy successfully.

We therefore find ourselves in the midst of a paradox in which the powerful dynamic of modernization -its chief form being that of structural adjustment- is increasingly draining off the force of democracy, while the consolidation of democracy demands an integrative, modern development process which is being blocked by the true characteristics and forces of the adjustment. Once again, the only tools that can be used to tear down this barrier are those of politics, namely, a socially integrative national policy.

Entrepreneurs are another fundamental element in this process, not only because of the shifts currently being observed in adjustment policies and in the ideologies of international organizations, but also because the programmed society itself is essentially entrepreneurial. Even the most quintessential of market operations contains a cultural element, and even the most indirect mathematical operation of making a rational choice contains a political component.

The question arises, then, as to how much autonomous capacity for action is possessed by each Latin American entrepreneur, and also how much of a truly entrepreneurial content there is in their actions and 
how much is actually of a cultural and political nature. Are they really still content simply to seek immediate economic gain and to continue to imitate the consumption patterns of the North? Why do they have to follow cultural patterns which are socially, economically and psychologically alien to them? What are they afraid of? And, finally, what is the real social and political culture of, for example, a Brazilian businessman who straightens his Italian tie every morning and summons up his faulty command of English? How do transnational corporations and their agents in Latin American operate in a cultural sense? Is it possible to regulate the cultural behaviour of these agents by political means? What image do local entrepreneurs project for their Japanese or Swedish colleagues? What practical concept and what rational programme in respect of privatization policies do entrepreneurs have? Are they truly modern entrepreneurs? What can the other social actors do to reinforce corporate action?

If questions of this sort were to be asked of different social and political actors, perhaps one would arrive at the conclusion, or at least the hypothesis, that in these new times the social and political (but not the cultural) actors are harking back in an uncreative way to the past, are experiencing what psychologists would call a form of cognitive dissonance; in the face of this new and changing programmed society that is emerging, they respond with forms of behaviour and beliefs that belong to the past, to the era of the nation-State, which has now run its course. At times, it even seems that the privatization process is functioning, in a political sense, on the basis of clientage and bureaucratic practices in which even those who are to be sacrificed are taking part.

Living in the past is not the same thing as maintaining a secret, essential bond with past experiences that allows them to be imbued with new meaning in the avatars of these new times. The Latin American labour movement was organized to defend people's jobs, grew to take on a political identity, and formed close ties with the State and with quasi-State nationalpopular movements and parties. Perhaps now a critical review of the best moments of its past will enable its members -as, indeed, the most lucid and economically better-off groups among them are already beginning to do- to forge a new position for the unions on the national scene with a modern and democratic agenda for the future.

\section{Bibliography}

Abramo, Lais (1986): O rescate da dignidade (A greve de 1978 em Sāo Bemardo), Master's thesis, São Paulo, Brazil.

Barbosa de Oliveira, Carlos (1992): Política de ajuste económico e sindicatos no Brasil, ISCOS/ICFTU/CLACSO International Symposium on the Response of Trade Unions, the Political System and the State to the Crisis and Structural Change: European and Latin American Experiences, São Paulo, Brazil, August (mimeo).

Bouzas, Roberto (1988): Los escenarios económicos internacionales de corto y largo plazo y América Latina: una revisión de algunas proyecciones disponibles, Proyecto sobre Ciencias Sociales, Crisis y Requerimientos de Nuevos Parạdigmas en la Relación Estado, Sociedad, Economía, UNDP/UNESCO/CLACSO Regional Project RLA/86/001, Buenos Aires (mimeo).

Calderón, Fernando (1988): Potenciar la sociedad para consolidar la democracia, Le Monde diplomatique, vol. 4, No. 222, Paris, August-September.

Calderón, Fernando and Mario dos Santos (1992): Lo sociocultural y lo político en la reestructuración, Santiago, Chile (mimeo)

Castells, Manuel (1988): Nuevas tecnologías, economía y sociedad, Madrid, Universidad Autónoma de Madrid.
CIEPI (Centre for International Prospective Studies and Information) (1984): Economie mondiale 1980-1990: la fracture, Economica, Paris.

(1992): Economie mondiale 1990-2000: l'impératif de croissance, Economica, Paris.

Céspedes, Roberto (1992): Políticas sindicales frente a la crisis: Paraguay, ISCOS/CFTU/CLACSO International Symposium on the Response of Trade Unions, the Political System and the State to the Crisis and Structural Change: European and Latin American Experiences, São Paulo, Brazil, August (mimeo).

Coutinho, L. and W. Suzigan (1990): Desenvolvimento tecnologico da industria e a constituiçao de um sistema nacional de inovaçao. Relatorio sintese, FECAMP (mimeo).

Da Silva, Luis Ignacio (1981): Lula sem censura, Petrópolis, Brazil, Ed. Vozes.

Da Silveira, Carlos (1992): Brasil: crise, politica industrial e sindicato, ISCOS/ICFTU/CLACSO International Symposium on the Response of Trade Unions, the Political System and the State to the Crisis and Structural Change: European and Jatin American Experiences, São Paulo, Brazil, Augusı (mimeo). 
ECLAC (Economic Commission for Latin America and the Caribbean) (1990): Changing Production Patterns with Social Equity, Santiago, Chile, March. United Nations publication, sales No. E.90.II.G.6.

(1992a): Comportamiento económico y desigualdad social (LC/R.1249), Santiago, Chile, Social Development Division, 29 December.

-(1992b): Imágenes sociales de la modernización y la transformación tecnologica (LC/R. 971/Rev.1), Santiago, Chile, Social Development Division, 17 March.

Feres, María E. (n/d): Ajuste económico y política laboral: visión sindical, Expert Seminar on Latin American Labour Relations, ILET, Santiago, Chile (mimeo).

Lanzaro, Jorge (1991): El sindicalismo en la fase poskeynesiana. Crisis y renovación en el fin de siglo, Cuadernos del CLAEH, Nos. 58-59, vol. 16, 2nd series, Montevideo, Latin American Centre of Human Economics (CLAEH).

Lazarte, Jorge (1992): Movimiento sindical y políticas de ajuste en Bolivia, La Paz, (mimeo).

Notaro, Jorge (1992): Consolidación democrática, estancamiento económico y propuestas sindicales: Uruguay 1984-1992, ISCOS/ICFTU/CLACSO International Symposium on the Response of Trade Unions, the Political System and the State to the Crisis and
Structural Change: European and Latin American Experiences, São Paulo, Brazil, August (mimeo).

Palomino, Héctor (1991): Respuestas sindicales y reconversión industrial, Seminario sobre reconversión productiva, Buenos Aires, August (mimeo).

Palomino, Héctor and Marta Novick (1992): Estrategia empresarial y respuesta sindical frente a la reestructuración económica. Estudio de un caso, Buenos Aires (mimeo).

Pérez, Guillermo (1992): Políticas sindicales frente a la crisis y a los cambios estructurales en Chile, Santiago, Chile, Centre for Humanistic Labour Studies (CELAH), July (mimeo).

Rivera, Alberto (1992): Políticas sindicales frente a la crisis y a los cambios estructurales en Bolivia, 1985-1992, ISCOS/ICFTU/CLACSO International Symposium on the Response of Trade Unions, the Political System and the State to the Crisis and Structural Change: European and Latin American Experiences, São Paulo, Brazil, August (mimeo).

Thompson, Andrés (1992): Economía, política y organización sindical. Argentina 1983-1990, ISCOS/ICFTU/ CLACSO International Symposium on the Response of Trade Unions, the Political System and the State to the Crisis and Structural Change: European and Latin American Experiences, São Paulo, Brazil, August (mimeo). 